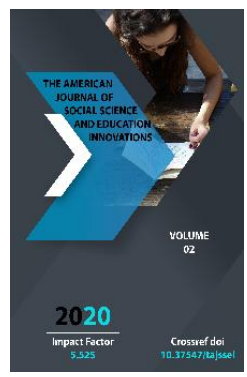

\title{
Part Of Professor In Advocate Conscience And Attitude In Insignificant Improvement
}

\author{
Dr. Mahesh Patel \\ Assistant Professor, Center For Studies In Social Management, Central University Of Gujarat, \\ Gandhinagar, India
}

Journal Website:

http://usajournalshub.c

om/index,php/tajssei

Copyright: Original

content from this work

may be used under the

terms of the creative

commons attributes

4.0 licence.

\section{ABSTRACT}

This paper looks at the function of educators in both multi-culture and multi-ethnic schools of A.P. Private Schools and single-culture schools, for example, Backward, plan class and Schedule clan government assistance schools. One of the objectives to grant esteem based instruction is to feed a responsibility towards comprehensive turn of events. To achieve this, it is basic that educators instruct appropriately, both in what they educate and by they way they instruct. This article investigates that, the thought by analyzing the key terms: 'training', 'morals in instruction', 'esteem based instruction', and 'social change'. To begin with, meanings of "instruction" are analyzed, and it is contended that how training is advancing moral qualities among the understudies through the function of educator and instructor training. This prompts a conversation of the idea of comprehensive development, which is introduced regarding three issues: incorporation and human instinct, liberated from discipline and provocation of auxiliary brutality on understudies, and individual pledge to morals. At long last, the idea of social change is inspected in its relationship to the thought of intensity, acculturation of instructor nature and character, to the significance of imagining a superior world, and to the significance of gathering activity. At last, study hall models are given that delineate manners by which both substance and instructional method can add to the objective of training for comprehensive turn of events and positive social change.

\section{KEYWORDS}

Teacher Improvement, Teacher job, multi-culture, single-culture schools, accentuation on esteem based instruction, morals, conscience, and social agreement. 


\section{INTRODUCTION}

Morals and qualities have been one of the most wanted necessities of human life since days of yore. Since the coming of sorted out human culture individuals are strived for the morals, conscience and qualities throughout everyday life, and are more joined today as they continued looking for harmony, congruity and a superior personal satisfaction. A solid need is being felt by improvementists, thinkers, researchers and political pioneers to restore the human qualities, which may get durable harmony society. Therefore, training for attitude incorporates an assortment of issues like basic liberties instruction, ecological training, kid rights instruction, global training, compromise training, fundamental abilities instruction and improvement instruction. A survey of projects on esteem based instruction for harmony in various nations shows that they vary extensively in philosophy, goals, accentuation on improvemental plan, substance and practices and so forth. For example in India, the training for harmony programs have been generally worried about advancing certain basic beliefs. The instructive arrangements of the nation lay weight on contentious part of training in taking out obscurantism, strict zeal, brutality, strange notion and submission to the inevitable, and advance some fundamental beliefs, for example, Indian social legacy, libertarianism, popular government, secularism, uniformity of genders, and teaching of logical temper. Harmony and living respectively have been vital piece of Indian method of living and showed in its Constitution through different articles. It immovably accepts that teaching of specific qualities among more youthful age would assist them with existing in the dynamic sociosocial texture with harmony, agreement and success. This is the motivation behind why all commissions and advisory groups on training in India, similar to, the Radha Krishnan Commission (1948-49), Mudaliar Commission(1952-53), Sri Prakash Commission (1959), Kothari Commission (1964-66), Sampurnanad Commission (1961), Rammurti Committee (1992) and Chavan Committee (1999), and so forth make significant proposals for consolidation of significant worth instruction at all degrees of instruction. Therefore, the National Curriculum Frameworks of 1975, 1988 and 2000 had embraced a worth situated way to deal with coordination of harmony worries in training.

\section{HYPOTHETICAL BACKGROUND}

Various ways to deal with 'esteem instruction' have been advanced by driving creators in this field. The methodologies are recognized by their suppositions that esteem instruction is principally either an) an information based subject that can be straightforwardly instructed in the school improvemental plan; b) a lot of aptitudes and perspectives that can be unequivocally educated or all the more unpretentiously mixed in an assortment of instructive settings; or c) a blend of the two.

1. The information based subject methodology: COPRED (1986) The US-put together Consortium with respect to Peace Research, Improvement and Development stresses the information segment of harmony/esteem training, characterizing harmony as a 'multidisciplinary scholastic and good journey 
for answers for the issues of war and shamefulness with the considerable improvement of establishments and developments that will add to a harmony that depends on equity and compromise.'

2. The abilities and perspectives approach: Cremin (1993) places a more noteworthy accentuation on aptitudes and mentalities, characterizing harmony instruction as - 'a worldwide term applying to every instructive undertaking and exercises which take as their center the advancement of an information on harmony and of harmony building and which advance, in the student, perspectives of resistance and sympathy just as aptitudes in participation, strife evasion and compromise so students will have the limit and inspiration, exclusively and on the whole, to live in harmony with others.'

\section{OBJECTIVES OF THE STUDY}

1. To Find out the entrance and value in multi-social and multi-ethnic schools of A.P

2. To know the educator part in advancing qualities and morals in multi-culture schools

3. To Explore the reasons how the instructor training would prompt worth based instruction in Insignificant Improvement of single culture schools

4. To inspect the explanations behind educator's brutal demeanor and beatings in government assistance schools

\section{METHODOLOGY}

The investigation was led utilizing a cross sectional study plan from an associate of respondents from chose optional schools to be specific Andhra Pradesh Residential Schools, Social government assistance schools, for example, Backward, Schedule Caste and Schedule clan. Auxiliary sources were first investigated to get from experiences into the writing on esteem training, harmony and concordance. The example depended on the data and information related to the targets of the examination were gathered from understudies and instructors in three haphazardly chose schools of unique classifications of multi-culture and singleculture schools of Andhra Pradesh with the example size of each school being equivalent corresponding to the quantity of educators and understudies in that specific school. Eventually, the example gathered from A.P. Private schools of 20 educators and 20 understudies, and 10 instructors and equivalent number of understudies from social government assistance schools of BC, SC, and ST schools. The instruments of information assortment were utilized which included organized survey, bunch conversations and inside and out meetings. The inside and out meetings permitted to acquire an extra data from respondents of the two educators and understudies.

\section{CONCLUSION}

The instructors the individuals who are instructing in the government assistance schools are badgering the understudies truly, explicitly and intellectually. In spite of the fact that they are going through preparing program about worth based instruction and good lessons, the disciplines are going on harshly, which prompts turmoil among the young lastly it drives the understudies to leave the school strongly. In our investigation we have cooperated numerous great instructors 
Doi: https://doi.org/10.37547/tajssei/Volume02Issue09-35

the individuals who are empowering the understudies towards advanced improvement, and further profession arranging. Among these three kinds of schools, the understudies from single-culture schools are confronting more disciplines, greater provocation and less associated just as low social presentation contrast with A.P. Private school understudies. The function of educators in A.P. private schools is acceptable in building the understudy's vocation than the two other Social government aides professor. The SC and ST government assistance teacher ought to be prepared appropriately so as to show harmony and concordance to understudies and make their life as significant.

Instructor has an extraordinary part in person's life. Taking into account that showing calling as imperial and compassionate, educators should control understudies as per the future difficulties, for example, compromise, great habits, and great conduct disposition through fundamental abilities instruction. At last, instructors have an incredible part in building the people in the future through worth based training.

\section{REFERENCES}

1. Aakash, K., 2005. 'Reevaluating the Paradigm of Teaching' Implication for Teacher Improvement. Vol.06 (5), pp.6575.

2. Crewman, P., 1999. 'Advancing instruction for harmony.' In Crewmen, P., ed., 1999, Improvement for Peace. Instructive Studies Association of Ireland and the Irish Peace Institute.

3. Licks, K., 1996. 'Instruction for harmony: issues, difficulties and choices'.

4. Gopinath., 'Harmony Improvement and Conflict Resolution in School'. Wellbeing Administrator, Vol.07 (2) pp.39-45. 